\section{COLONIALISM AND POSTCOLONIALISM IN SCIENCE FICTION FOR GREEK CHILDREN}

\section{Georgios Papantonakis ${ }^{1}$}

\begin{abstract}
In contemporary Greek history we do not encounter the historical and social phenomena of colonialism or postcolonialism with the exception of cases where nations conquered Greek islands; the Dodecanese Islands and the Eptanisa (Seven Islands) were conquered by the English and the Italians, and Cyprus was conquered by the British in the Middle Ages and in contemporary times. These historical situations have been transferred into certain historical Greek fictions in adult literature and in the literature of children and young adult. The focus of this essay is on investigating and depicting colonialist attitudes and post-colonialist situations in science fiction for Greek Children. Initially, we attempt a brief introduction to the literature of children and young adults and mainly science fiction for children in Greece, and following this we outline the aims of our research. Then we define the terms "colonialism," "postcolonialism" and the new suggested terms "historical colonialism" and "literary colonialism" and refer to their relationship with science fiction. This is due to the fact that the setting of these narratives "is dictated" by a group of events that the writers themselves have either brought about or believe will take place in the future.
\end{abstract}

\footnotetext{
${ }^{1}$ Assistant professor, University of the Aegean, Greece
}

Afterwards we point out the criteria that are used to distinguish between five types of colonization in the texts and we investigate at greater length the role that children and adolescents play in the texts, as they participate actively as liberators and saviors, as protectors for peace and the environment or as characters that take on the roles of adults. The children and young adults remain passive spectators of a peaceful colonization or do not participate in the action since the heroes in the story are insects. In this case, they are limited to the role of reader. Through the study of these texts, we detect similarities to similar situations, both in antiquity and at a later date, or during contemporary times where similar policies in certain countries have been regarded. Finally, we realize that after the inversion of colonialism and the liberation of the colonized planets, these planets are governed democratically, according to Plato's and Aristotle's ideas on politics.

\section{Introduction}

In Greece, children's literature showed very little activity in the second half of the nineteenth century; however, the fall of the military dictatorship (1974) triggered a swift development. Contrary to this, literature for adults showed a remarkable development and outstanding authors made their presence felt (e.g. Papadiamantis, Palamas, Seferis. Vrettakos, Elytis). Science fiction had appeared in literature for adults by the end of the nineteenth century, similar to world-wide literature and centered upon space travel (Jule Verne, H.G.Wells).

Literary voyages to the Moon of course, even if they are more of an imaginary rather than scientific nature, began in Greek antiquity with the texts of Lucian of 
Samosata's Alithis Historia (True History) and Icaromenippos 'Icaromenippus.' In the $19^{\text {th }}$ century, texts were written for adults featuring journeys to various planets. In Taxidi ston Planiti Dia 'Voyage to the planet Jupiter' by Andreas Laskaratos (1888), the hero goes on a journey to Jupiter, riding on a sunbeam. Demosthenes Voutyras in his novels Apo ti Gi ston Ari 'From Earth to Mars' (1929), Stous Agnostous Theous 'To Unknown Gods' (1930) and Kalpikoi Politismoi 'False Civilisations' (1934) takes the reader to strange worlds in equally strange machines, modelled on those of Jules Verne.

Over the last forty years, writers, in general, and especially science fiction writers who wrote for adults or children and/adolescents, broadened their themes to include other issues that were of interest contemporary man such as cryonics, the cross-breeding of species, cloning, nanotechnology, ecology, ecofeminism, etc.

The social and political circumstances that prevailed in Greece after the restoration of democracy in 1974 generally favoured the amplification of these themes in children's literature. Furthermore, influences from other countries, mainly in the West, and the development of the science favoured the amplification of these themes in children's literature.

In addition to this, other problems that occupied mankind in general and Greek people specifically during this period, such as urbanisation or ecology, were encompassed in stories by Greek authors who wrote for children and young adults. These themes are to be found in science fiction adventures, a literary exposition of plot that charms both children and adolescents. Therefore, through the aesthetic reading of science fiction for children and young adults, the writers bequeathed their ideological values while avoiding apparent didacticism.

The first literary science fiction text for children and juveniles was written in the decade of 1940 by Petros Pikros. Its plot is a space adventure, a subject that is popular with young readers and most enthusiasts of adventure. Essentially however, science fiction for children and young adults began flourishing after 1980, when there was an upsurge in the production of literary texts with richer themes for children and young adults.

It is possible that the writers of these literary texts were influenced by the attempts of both American and Russian scientists to discover space in the 60's, as can be seen in certain texts of minor literary value (Vasilis Paschos's The Extraterrestrials Surprise Us (Paschos 1979b), The Astronaut The Conciliator, (Paschos 1979a), A Travel To The Stars (Paschos 1989)). Writers were, furthermore, influenced by articles in the press about extraterrestrials threatening the Earth.

However, Greek science fiction was not influenced by Hollywood films (e.g. ET, The extraterrestrial, 1982, that played in Greece on December 31, 1991) because these films were produced at a later date, i.e. after the Greek science fiction for children and young adults. The extraterrestrials are always depicted as being friendly towards the inhabitants of the Earth, for the reason that the authors do not wish to frighten the children and wish to protect them from the point of view that extraterrestrials may be hostile. The only exceptions are two science fiction texts written by the Cypriot female 
author Tulla Kakulli that were published in the 1980's. These texts were the first science fiction texts to be published in Cyprus. In both texts, the extraterrestrials are not apparently hostile but their plans suggest a colonial policy, regardless of their failure to put it into effect in the end.

However, most of these texts and those that followed in modern and contemporary literature for Greek children and young adults, simply describe trips and visits to planets. In the very few science fiction texts with a colonial and postcolonial orientation for children and young people in Greek children's fiction, the most popular destinations are the Moon and Mars.

Therefore, in Greece, colonial and postcolonial literature is not widely represented, as it includes only texts we analyze (for the time being), and postcolonial science fiction criticism in children's literature is limited to very few instances (Papantonakis 2005).

The advances in technology and man's efforts to colonise space, in accordance with the model of the ancient Greeks or the later Western European colonies, necessarily lead to linking colonialism and postcolonialism with science fiction. This link requires investigation in terms of the behaviour of contemporary colonists and the reaction of the creatures that may conceivably exist on the host planets. Thus, we will be able to ascertain to what degree the colonial and possibly imperialist policy developed in the case of colonization on Earth has been differentiated in space, in terms of its causes-the increase of living space and exploitation of natural resources-and of the means used, in an age when the explosive development of technology and the colonization of a country on Earth or on another planet has become easier than it was in the past. Research should also investigate the roles of aliens in science fiction. So, our research is directed towards the possibility that extraterrestrial beings (if such exist and they certainly do exist in literature) may be developing similar colonial and imperialist policies either towards the Earth or towards other planets, and for what reasons. However, the most basic and the most important issue in our research is the role of children in colonial/postcolonial science fictions. Do they remain mere observers of what happens in these stories or do they take an active part? And if they take an active part, do they support the colonial and imperialist plans of the adults, or do they oppose them? To what degree does the participation of children in colonial stories serve the objectives of children's literature and in particular those of science fiction? Finally, are these space stories solely space-related or do they also have allegorical meaning and do they recall colonial periods in the history of the human race in an updated version? We shall endeavour to answer these questions by studying the very few Greek children's science fiction texts of a colonial nature. This essay also considers how children can change society through postcolonial science fiction.

The following methodology was used. Initially, we studied Greek science fiction and categorized it according to the criteria outlined below. Following this, we outlined the specific texts, which, though few in number, were relevant to our research. These texts are analysed in the present paper. We defined the term "colonialism" and the two terms we proposed: "historical colonialism" and "literary colonialism." These texts we then 
classified into five types of colonialism, according to their content, in an attempt to describe the phenomenon in more detail. Following this, we studied the roles that children undertake in these science fictions in more detail, taking into consideration the types of colonialism that were recorded. Finally, we outlined our conclusions.

\section{Defining colonialism and postcolonialism, "historical" and "literary" colonialism}

Before we define the terms "colonialism" and "postcolonialism," we need to comment on their form. Both terms are the subject of much debate among scholars who often use them in confusing ways and this makes it difficult to define the terms. ${ }^{2}$ Critics have not yet agreed if they should spell "postcolonialism" with a hyphen (post-colonialism) or without. We will refer to the term as a single word, "postcolonialism" because of their different meanings. The hyphenated term "post-colonial" seems more appropriate to denote a particular "historical period," as with those suggested by phrases such as

\footnotetext{
${ }^{2}$ A recent essay by Russell Jacoby (1995) complains that the term postcolonial has become the "latest catchall term to dazzle the academic mind". Squabbles over the definition of 'colonialism' and even over the meaning of 'post' extend to a confusion over "postcolonial studies" so that "enthusiasts themselves don't' know what it is". He adds that lots of theory is written in a confusing manner and the critics accuse each other of complicity with colonial structures of thought though the criticism's declared intention is to allow the voices of once colonised peoples and their descendants to be heard, it in fact closes off both their voices and any legitimate place from which critics can speak (Loomba 1998: xi)
}

"after colonialism" or "after independence." However, in our paper we use "postcolonialism" not just in terms of strict "predication" but to refer to disparate forms of representation, and values as McLeod (2000: 4,5) argues.

The term postcolonialism has become so heterogeneous and diffuse that it is impossible to satisfactorily describe its exact meaning. This difficulty is partly due to "the inter-disciplinary nature of postcolonial studies which may range from research in the archives of colonial government to literary analysis" (Loomba 1998: xii). "Colonialism" is often used interchangeably with "imperialism," however, the terms mean different things. Imperialism is the ideological concept which upholds the legitimacy of the economic and military control of one nation by another and it does not demand the settlement of different places in order to work. Childs and William (1997: 227) define imperialism as "the extension and expansion of trade and commerce under the protection of political, legal, and military controls." Colonialism, according to the Oxford English Dictionary, comes from the Latin colonia which meant "farm" or "settlement." The Romans settled in other lands but still retained their citizenship. Colonia describes "a settlement in a new country . . . a body of people who settle in a new locality, forming a community subject to or connected with their parent state; the community so formed, consisting of the original settlers and their descendants and successors, as long as the connection with the parents state is kept up." This definition avoids any reference to people other than the colonizers. In these terms, colonialism is one historically specific experience of how imperialism can work through the act of settlement and it can be 
defined as the quest and control of other people's land and goods. Therefore, colonialism is only one form of various practices which have produced a variety of fiction and scientific literature.

In our paper, we use two new terms, "historical colonialism" and "literary colonialism." The first term refers to specific historical periods in which colonialism flourished, a historical fact viewed as an historical event that is researched by historians, sociologists, anthropologists and others and can be depicted in literary texts for adults, children and adolescents. When colonialism is depicted in literature, this representation aims to portray a historical past that no longer exists and to spread ideological values that are related to the phenomenon through the aesthetic reading of the literary texts.

These texts have interpreted the past as implicitly recording the colonialism and postcolonialism of historical memory. In antiquity, the Greeks established colonies in geographical regions known to them, from the coasts of the western Mediterranean (Spain and North Africa) to the Black Sea and the Caspian Sea coasts to expand their living space. Later, Western European countries sought outlets for settlers and economic exploitation in regions remote from their homeland (e.g. India etc). Literary texts that are based on historical facts, such as these, can be considered "historical colonialism" and not "literary colonialism" which is studied in this present paper. These stories would normally be considered "literary colonialism" if the only aspect considered were their historical nature; however, both story and plot constitute them as social, psychological or political science fiction.
On the other hand, scientific progress and the discovery of other planets has inspired many authors to locate their stories on known or imaginary planets to which people have gone as ordinary travellers or as conquerors and colonists. In this case we have a type of "literary/science fiction colonialism" because it is depicted in literary narratives, regardless of whether the inspiration is due to similar cases in human history.

Therefore, we use the term "literary colonialism" to refer to the literary tendency for a colonial theme to be described with reference to the future, due to the futuristic character of science fiction both for adults and for children and young adults, and seldom to the past, when referring to travel through time. This characteristic is frequently evident in titles of books (e.g. Gi 2040 m.X. 'Earth 2040 $\left.\mathrm{AD}^{\prime}\right)$.

This shift from the past to the future is dictated by two factors. The first has to do with location. Colonial/postcolonial stories take place on other planets owing to conditions that have been created for which man is responsible, such as the destruction of the environment by nuclear energy. The second reproduces the same economic, political and ideological reasons used to justify all colonisation. The differentiation lies in the location of the colony, in the time required and means used by the colonists to impose their presence.

In any case, the settings in all these narratives "is dictated" by a set of events that the authors themselves have created or the belief that these events will take place in the future (e.g. nuclear disaster). 
So, we use the term "literary colonialism" to designate a literary style which considers older forms of "historical colonialism" and adapts its themes to the demands and characteristics of science fiction, through the utilization of technology as a "blessing," when considering what it allows you to do, as well as a "curse" when considering disasters that can come about as a result (nuclear disaster, ecological effects, etc.). Therefore, literary colonialism clearly belongs to the sphere of science fiction both for adults and for children and young adults, and this is why literary colonialism differs from historical colonialism.

"Literary colonialism" may imply real colonial situations in literature generally but rarely in Greek children's and young people's literature and perhaps more often in literature for adults.

\section{Greek children's and young adults' colonial and postcolonial science fiction: criteria and types of colonialism}

Although a lot of children's and young adults' novels that describe travels to space or visits to Earth by extraterrestrials have been written in Greece, the literary texts we study in this paper are only those with colonial themes. In other space science fiction for children and young adults, we simply have travels by earthlings, both adults and children, to discover space or friendly visits to the Earth by extraterrestrials, who aim to communicate with other beings (earthlings) or to teach others about their civilization. We must say at this point that research on the World Wide Web did not reveal a list of science fiction for children and young adults with colonial themes but this does not mean that novels with colonial, anticolonial or postcolonial themes do not exist worldwide.

These few Greek science fiction texts for children and young adults, in which the themes of colonialism and postcolonialism are depicted, can be grouped into five types of colonialism. The criteria we took into consideration in attempting a taxonomy of the literary texts are the following:

1. A basic criterion is that these literary texts have to be Greek children's and young adults' science fiction and that they must describe colonial or anticolonial situations. This means that it was necessary to take into account both the subgenre of science fiction and ideology.

2. Even if the colonial or anticolonial situations which are described in the text are not the main topic but a secondary theme in the literary text, we decided to examine these texts. In this case, colonialism is due to the disposal of a society by its non active members or to its salvation due to environmental disaster.

3. The role of the children or young people in these stories was the most serious criterion. In the first of the following types of colonialism, the children play no role. The heroes are insects, which symbolize adult colonizers. In the last one the children are simply onlookers or eye-witnesses. In the other stories, children have a determinative role and emerge as a vehicle for new ideas, based on 
their beliefs about freedom which they express and their demonstrated respect for other people.

These six science fiction texts with colonial themes in children's and young adults' literature are: Isvoli stin Myrmigana 'Invasion of Myrmigana' by Marios Verettas, Gi 2040 m. X. 'Earth 2040 AD' by Takis Androutsopoulos, I Teleftaia Xora sti Gi 'The Last Country on Earth' and Ora Miden 'Zero Hour' by Toula Kakoulli, To Mynima 'The Message' by Vassilis Papatheodorou and I Mihani sto Ypogeio 'The Machine in the Basement' by Kira Sinou. These literary texts can be grouped into the following types of colonialism:

1. Intergalactic colonialism and postcolonialism. This category includes the text Isvoli sti Myrmiganal Invasion of Myrmigana by Marios Verettas which is characterised as having a strong colonial nature, where the imperialist policy of the inhabitants of one planet in a galaxy is to the detriment of other planets in the same galaxy. In this story there is no reaction by the colonizers and the fictional characters are insects which symbolize adult imperialists and colonizers (Myrmiges) and subjected people (all the anonymous planets except Tzitzikoni) which resist the colonial policy (Cicadas).

2. Anticolonial. This category includes the science fiction Androutsopoulos, Gi 2040 m. X. / Earth 2040 AD that is substantially anticolonial in nature. The fictional characters who are children are characterized by anticolonial ideas, in contrast to the adults, because they believe in freedom for all people in the world and all beings on other planets. The example is a text in which children prevent the harsh colonization of the planet Mars by adults. The child colonists behave with absolute respect for the Martians, whom they help to restore their environment that has been destroyed by nuclear energy and to live in peace with them. The difference between these two types of colonialism is that in the first one anticolonial views are not expressed nor do anticolonial movements take place by any group of imperialist colonizers or colonial subjects. On the contrary, in the second type, the children not only disagree with the adults' colonial plans and objectives but they actually react by stealing the spaceship from the adults, depriving them of the possibility of landing on Mars as colonizers and exploiting it financially. Therefore, by travelling to Mars, they become heroes. Thus, we have "children-saviours" in contrast to colonizers-exploiters of the first category.

3. Threatened colonialism of Earth by creatures from other planets with texts in which the extraterrestrials or androids plan to conquer and colonise Earth, which is eventually saved by children or by the change in extraterrestrial spies, as they make friends with the children and are charmed by the depth of their feelings (Kakoulli, I Teleftaia Xora sti Gi / 'The Last Country on 
Earth' and Ora Miden / 'Zero Hour').

4. Planetary marginal coloniality presented as edenic. This type of colonialism includes the text To Mynima / The Message by Vassilis Papatheodorou in which the purpose of colonization is to expel the weak thereby ridding society of them. The society is authoritarian in nature and tyrannises its citizens. This text also belongs to space science fiction since people from the Earth who are unable to work are moved to two asteroids. They are promised a paradise but in fact it is a form of expulsion which leads to ghettoisation.

5. Ecological colonisation. The last type of colonization comprises the text I Mihani sto Ypogeio / 'The Machine in the Basement' by Kira Sinou in which colonialism is made necessary for ecological reasons. In this case, the people of the Cretaceous period are obliged to colonise another planet, but with peaceful purposes, owing to the environmental destruction on their own planet. Here reference is made solely to what caused the colonization and to the departure of the colonists, without describing the conditions of the colonization or the postcolonial situation. The intentions of the colonists are good, as they just want to save themselves, which means managing the host space and harmonious co-existence with the inhabitants of their destination planet. In fact, in all Greek colonial science fiction, colonialism has been made necessary for ecological reasons. In these Greek children's and young adults' colonial science fictions pollution of the environment is wide-spread (on Earth or on other planets, e.g. Mars); however, the polluted environment is not abandoned in any of the texts, except in the novel The Machine in the Basement.

In these texts, oppressed people (or other beings) seek their "national" identity and an autonomous cultural self, as they are obliged by the dominant culture to reconstruct the myth of their independence and to reshape their national and cultural identity.

\section{The role of children}

Studying the above science fiction with colonial themes, both reader and researcher discover that children play a very important role in most of the most colonial and anticolonial stories because they express anticolonial ideas and are therefore ambassadors for a peaceful cohabitation between the people Earth and the harmonious coexistence of the Earth with other planets.

Children are only spectators in cases where the colonization is necessary and does not involve exploitation (The machine in the basement), but in all the other texts they are engaged actively and participate in anticolonial struggles. Furthermore, some scholars (Stephens 1992: 120-157, McGillis 1999: 225) consider the children themselves as subordinate or suggest it. This concept is based on the relationship between the adults (colonist) and children (subjected people). So, their "emancipation" from 
oppression by adults emerges through anticolonial ideas which they externalize and represent. Only in the novel Invasion of Myrmigana by Verettas, in which the heroes are insects, are there no children.

The children in these colonial stories serve the objectives of children's literature and in particular, the objectives of children's and young adults' science fiction, since they participate actively in all the stories which we studied and which belong to this subgenre of literature. We must say that all these stories constitute a new version of "literary colonialism" which we can call "science fiction colonialism," in which children and young adults play a very active role.

The roles that the children-heroes undertake in these stories are not always distinct because these roles very often overlap. So, for instance, the young heroes prevent the colonization of a planet and they become saviours, but, at the same time, they emerge as defenders of liberty, protectors of the environment and thus take on the roles of adults.

\section{Children as preventers of colonization and protectors of the environment}

The most important role that young fictional characters undertake in Greek science fiction with colonial themes was in their attempts to ward off the plans for colonialism and exploitation of the planets that the adults intend. This basic role results in other roles that come about due to situations that arise, i.e. protectors of freedom and the environment. This role that reveals the anticolonialism of the children is represented in Greek children's and young adults' literature by Takis Androutsopoulos's science fiction Earth $2040 A D$, written collectively by the author, as teacher, and his 21 students. Briefly, the inhabitants of Earth, after a nuclear disaster, live underground and are preparing to colonise the planet Mars. The children discover the adults' plans and thwart them by stealing the spaceship, which they use to travel to Mars to settle peacefully and cooperate with the Martians. The adults, however, manage to build another spaceship in which they travel to Mars and subjugate the Martians and their own children, who eventually succeed in taking control, expelling the adults and living peacefully with the local people.

The author here gives the reader an opportunity to compare the behaviour of the two sets of characters. The first set are the Martians and the children who came from Earth to forestall the conquering, colonial intentions of the earthling adults. The young heroes prevent the colonization of Mars and become its protectors and saviours. They also become its saviours for one more reason. The children, who find the Martians destitute and miserable because of the destruction of their atmosphere by nuclear energy try to help them as much as they can and gain their confidence. Thus communication is established between them and they learn the secret of how to restore the devastated environment ${ }^{3}$ through the use of advanced technology eventually going on to co-exist peacefully with the Martians. But the same

\footnotetext{
${ }^{3}$ Science fiction writers have a great advantage in that they can design their own enemies (Dish 1998: 165). Where, in H.G. Wells's The War of the Worlds (2006), the invading Martians were destroyed by Terran bacteria against which they had no immune defence, in Earth $2040 A D$, the Martians are destroyed because of the environmental pollution they have thoughtlessly caused themselves.
} 
does not hold for the second set of characters.

It is evident that children are protectors of freedom for the Martians and that they represent an anticolonial policy when they free the planet, send away the conquerors and, once again, take control after the leaders of Earth, some of whom are the parents of these children, reach Mars, conquer it and impose harsh colonial rule.

The difference in the goals and behaviour of the adults as colonists and the corresponding goals and behaviour of the children is obvious and confirms the missionary character of science fiction with children as heroes. Among the former, we can discern a purely colonial and imperialist policy, with the intense oppression and exploitation of the colonised planet and its colonised inhabitants (Martians and earthling children). The children, under the leadership of their enlightened teacher, are imbued with peaceful feelings and a desire for collaboration, mutual understanding and solidarity with the Martians; they are full of humanity and at every moment they resist the colonialist plans of the adults. They seem to be ideal children, like those who have not yet been born, on whom all of humankind places its hopes for the future:

"We have decided to impose the conditions of our collaboration and we do not accept false dilemmas, such as: for the benefit of humankind, we are unique and that our destiny has chosen us to be the first young explorers of space." (Androutsopoulos 1999: 174).

Their peaceful intent and the role of the children-doers are also reinforced in the poem by the Greek poet, Nikiforos Vrettakos, that the children send to their parents on Earth:

$$
\text { ... Lord... }
$$

Help me to become a doer, and give me time to light fires, to help open roads that meet, to de-pollute the earth. To make the dream come true:

For two suns to rise in the firmament, one in the abyss of space, as always, and the second, the other, Love, in the human abyss.

(Vrettakos 1990)

\section{Children in adult roles}

In the same novel by Androutsopoulos, as the children have to be organized into societies, they undertake the roles of adults. After the children prevail over the adults, thereby preventing the cruel colonization of the planet, they begin to organise social and cultural institutions and to create families. It is the only colonial science fiction in which they grow up, fall in love and create their family and a utopian society.

The postcolonial situations that are created lead to a closer social organisation and institutions that may not be far from the earthly model in terms of their form but are, however, differentiated in terms of their essential content. We follow their vision and the means whereby they will succeed in their mission without any violence from the powerful through a hero's words:

"First, I must thank God who gave us the privilege of being those that will strive to create a better society, that is more ethical, that is void of the passions and the violence of the powerful. Then we will consider the 
life that awaits us and believe that...we cannot do other than be successful here as well" (Androutsopoulos 1999: 221).

The children, who in the meantime have become adults, do not shed their innocence; they do not abandon their goal of peaceful co-existence with the Martians, but co-exist on an equal basis. Their postcolonial behaviour is in harmony with Platonic and Aristotelian views about citizens and their relationship with the state. Despite its organisation in accordance with earthly models, freed of its negative aspects (violence, financial exploitation, etc.), the society appears utopian; it is however present in the imagination and established in a place far from planet Earth, in collaboration with the inhabitants of the host planet.

If we accept that this story not only traces children's coming of age but also records the conflicting discourses that organise and encode their subjectivity (Dalziell 2004: 39), then the first words, as in Vrettakos's lines that we read above reflect this maturation. The words, spoken after their departure for Mars, mark the resoluteness and constancy of the children in rejecting a crumbling and corrupt society and, through their relocation on Mars, in building a healthy society and economy without exploitation not only of humans but also of the "colonised" Martians.

Earth $2040 A D$ should be considered as a colonial and postcolonial literary text that treats man and the colonised place as an intrinsic and not an instrumental value. Values emerge through its colonial and postcolonial themes that make this book a fundamental text setting the pattern for anticolonial fiction.

\section{Children as protectors and as saviours of social and political stability}

The role of the child-protector is met in many fields of Greek colonial science fiction for children and young adults. Both society and politics are among them. The children take on the role as protectors of society and soldiers for political stability in Vassilis Papatheodorou's book The Message, in which colonialism is not the central theme of the novel. In the beginning, the narrator informs the readers:

"Lately two more colonies were established on great asteroids; one that would become a Global Jail and the other that would be something like a Global Institute. But for the last one more details were not given. In this way, the Earth would be relieved of some from its enormous population and the life of the inhabitants of the Earth would be regulated better." (Papatheodorou 2001:7).

The story does not describe life in the colony, which would have been very difficult, as can be seen in a message that reaches the two child protagonists, Cosmo and Aris. This message actuates the setting for a politic dystopian story to develop. Through colonization of the two Asteroids the real face of a political utopia is discovered and it is, in reality, a dystopia because the ruler governs in a despotic and authoritarian way. However, this magisterial control is not realized by the citizens because the system is perfectly organized. Both this discovery and the restoration of social and political stability are accidentally brought about by the young protagonists in the story, who in the 
beginning act as detectives who try to discover where the message has come from. Thereafter, the children bring about the restoration of social and political stability.

As soon as Cosmo, the hero, receives the message for help on his computer, he and his friend Aris take action and rush to help. The two young friends search for the origin of the message, find it and reveal the real colonial plans of the authoritarian regime, which they put an end to: "The people would read the message right away and would be informed about the Global Institution and its Great Program that would fail (Papatheodorou 2001:144). ${ }^{4}$

\section{Children-heroes as passive observers of colonialism}

In science fiction for children and young adults dealing with various themes, including colonialism, we rarely come across children as passive spectators of events. In the novel by Kira Sinou, The Machine in the Basement, we discover that children are the passive spectators of a peaceful colony. Although the basic theme of the novel is not colonization, the people of the Cretaceous, the period to which the children have been transferred through a time machine, abandon their planet because the environment has been destroyed. Through the eyes of the

\footnotetext{
${ }^{4}$ Something similar happens with Jonas as well who helps Gabriel to escape to Elsewhere in the fiction The Giver by Lowry (2008) in which we do not have a colonial situation, but merely in a wider sense, as expressed by McGillis (1999: 225) a story about children who are the colonized and adults who are the colonizers. In reality, the magisterial authority colonizes its citizens, regardless of the utopian mantle in which it appears.
}

children we witness only the departure of the colonists. What is interesting here is that the colony on the other planet was created after an environmental disaster; however, the reason is not mentioned and the event took place hundreds of thousands of years ago. This novel is also different from others for two reasons. Firstly, the children simply witness the colonization and do not want to participate in it and they intend to return to the time period they belong to. Secondly, the novel is examined by us because the people who leave their planet to settle on another do not intend to exploit the planet that they have travelled to but try to save themselves from the polluted environment, on one hand, and save themselves from the threat of dinosaurs, on the other, since the story takes place in an area where dinosaurs exist. The colony in the novel, however, constitutes a secondary and not main theme. Although it is the result of environmental pollution, it gains greater value since it seems to have peaceful goals.

\section{The role of extraterrestrial children and children born on the Earth}

\section{The transformation of the adult extraterrestrials into a child-spy and the earthling child as a guinea-pig}

It is a characteristic of both novels written by a Cypriot female author, Toula Kakoulli, who established science fiction in Cypriot children's and young adults' literature, colonialism is planned by (Zero Hour (1990)) or takes place (The Last Country on the Erath (1990)) because of extraterrestrials. In the first novel the extraterrestrials intend to intervene 
because there is no peace on Earth, which is bedevilled with wars:

\begin{abstract}
"Earth also, he continued speaking boomingly, must be conquered as soon as it is possible, since its inhabitants are not capable of either governing it or living there peacefully. Everywhere you look on this planet, you will see the fire of war. We, as superior beings in space owe it to assume authority and colonize this planet, before it has totally been destroyed by its inhabitants." (Kakoulli 1990:11)
\end{abstract}

As the colonization of the Earth by the inhabitants of the planet Teuthra aims to establish eternal peace on the Earth, i.e. a pacem aeternam, the extraterrestrials send a spy to take the place of an earth-born child which, in turn, is transported to the planet Teuthra, so that the extraterrestrial scientists can use it as a guinea-pig in order to study his brain and find what causes the warlike behaviour of the earthlings. Thus, the earth-born child involuntarily becomes a guinea-pig so that the warlike behaviour of the earthlings can be changed. This specific role can be integrated into the wider role of the childprotector of the peace. However, we must differentiate this role from the other because the earth-born child is used involuntarily as a guinea-pig for peaceful purposes. Therefore, the earth-born child has no consciousness of his role, in contrast to the extraterrestrial spy-child who undertakes an investigative role. Their spy, transformed into the child which the Teuthrians have stolen, is taught values that characterize the inhabitants of the Earth. He sees that children want to stop the wars and by expressing these desires to the governors of the planet Teuthram, he manages to save the earthling guinea-pig and to cancel the Teuthrian's colonial plans. Therefore, the role of the extraterrestrial adult, transformed into a child, is quite important because he is transformed from a passive witness into an active agent so that the child guinea-pig can be saved and so that the colonization of the Earth, which is now peaceful, can be prevented.

\section{Child protectors of the peace}

In The Last Country on Earth, a novel by Toula Kakoulli, where the Earth is running the risk of being colonised by extraterrestrials, similar to the science fiction novel ' $\Omega \rho \alpha M \eta \delta \varepsilon \dot{v} /$ 'Zero Hour,' where earthlings do not respect their environment, the children involuntarily save the planet and promote peace. It is apparent that although children initially play a neutral role because they are not aware of the situation, later they emerge as saviours of their planet and the protectors of peace. In fact, in the this novel, the unofficial, secret colonization of the Earth by extraterrestrial anthropoids has already taken place but it is reversed because the children of Earth have managed to inspire feelings in an anthropoid child, resulting in the unmasking of the colonists and obliging them to leave the Earth.

In this novel, the Earth is colonized by Anthropoids in order to exploit the inhabitants who have remained on the Earth (this fact justifies the title of the novel), for whom moreover they spy. Among the Anthropoids there is a child who is the most perfect robot that technology has invented and who plays an important role as he involuntarily puts an end to the final colonization of the Earth. His role is initially neutral, however, as the story evolves the child-Anthropoid is transformed into a friend of peace. His 
relationship with the children on the Earth transforms him into a human being since he acquires a heart and emotions so that he becomes removed from the Anthropoidcolonizers. The role of the children, both extraterrestrial-anthropoid and earthlings, makes the allegory evident. On one hand, man believes that the extraterrestrials are dangerous and he depicts them both in literature and in films in this way but on the other hand he thinks that they are more developed in technology than he is. In addition, he believes that the love that is detected in children can transform an extraterrestrial-colonizer and give him essential human qualities:

"The heart constructed by humans, the leader began to say, was created in the breast of the robot A-D, because a group of human beings, called children, loved and trusted him ... The study of our scientists, considering the data of the case of the robot, reached the conclusion that the phenomenon LOVE will transform it into a complete man." (Kakoulli 1990: 89, 96)

\section{Children as non actors in the story}

In our research we also found science fiction in which the heroes are not human beings but insects, i.e. myrmigia (ants) and tzitzikia (cicadas) and the entire story is an allegory. Both children and young adults are involved in the story merely as readers who read a story that describes the transition from intergalactic colonization to a postcolonial situation in the science fiction novel, Invasion of Myrmigana by Marios Verettas. In the "story for 'big' children," as characterized by the author himself, the young as well as adult readers exploit the colonizers unmercifully.
Marios Verettas's Invasion of Myrmigana (1997) is the only science fiction novel for children and young adults in which imperialism and colonialism are deified. There are no young protagonists, i.e. children or adolescents, to react against this situation, as seen in the other literary texts of science fiction that we have researched. However, once again, the overthrow of the colonial policy comes about as a result of a "child"-insect, a young female cicada. The brief speech by Myrmigas the Wild to the Council depicts both the whole colonial process and the imperialistic policy of Myrmigana:
"Up with system!" Myrmigas the Wild agreed with his audience. "Thanks to the Systema thousand years ago we succeeded in subjecting all the planets that were inhabited ... Thanks to the System our Myrmigana has become the master planet of the galaxy MM-T! Moreover, do not forget that thanks to the System we secured the privileges of the "plumy tribe" of Myrmigan commissioners." (Verettas 1997: 66)

The third person narrator indeed describes the situation in the most brutal way: "The galactic empire of Myrmigana has been created, developed, expanded, and dominated thanks to the miraculous diligence of its subjects. Both the administrative and financial system of the empire is functioning perfectly" (Verettas 1997: 25).

The text expresses, par excellence, a colonial space policy in conjunction with an absolutist system for the governance of space. The ideological context of the book is structured around the powerful planet of 
Myrmigana $($ myrmigi $=$ ant $)$, which has subjugated all other planets except for Tzitzikoni $(t z i t z i k i=$ cicada), which is ruled by an anticolonial democratic government that eventually succeeds in overcoming and overthrowing the colonial policy of Myrmigana. The names of the characters in the novel are characteristic: Myrmigas the Great (as in Alexander the Great) and Myrmigas the Inexorable (as in Ivan the Terrible), underscoring the colonial and imperialist nature of the situation. It is worth noting the cruel nature of the power wielded over the Myrmigans who are organised in a strict socio-political hierarchy.

The entire Myrmigan policy is initially reminiscent of the ancient Athenian hegemony and then of later alliances of an imperialist nature, irrespective of their political ideology. In Athenian hegemony, the Athenians forced their subordinates to pay hard tributes. The ancient Romans exploited the people whom they had conquered economically. Contemporary powerful countries dominate other weaker countries; they manipulate them and meddle in their affairs of State. The author describes the socio-political and ideological systems persuasively. The shift that takes place in the intergalactic colonial regime of Myrmigana, in conjunction with the change in the inhabitants' nature and attitude after the collapse of their colonial system, reflects colonial and postcolonial policy at all periods. The anticolonial, peace-loving Tzitzikes (Cicadas) stand up to the colonising Myrmigans (Ants) and manage to overthrow the latter's colonial policy using peaceful means. In the intersolar system, one and only one intergalactic anticolonial federation rules and its president is a Myrmigan poet.
The political allegory is obvious, as a reflection of Greek antiquity - e.g. the Delian League, which transformed allies into tributaries - including political systems and ideologies and even Platonic political thought, since power was ultimately assumed by an intellectual, in accordance with the Platonic recommendation that philosophers should rule or kings should become philosophers (Plato 1958). It is worth noting that the theories of Aristotle (1954) regarding the citizen as the basic component of the city are not undermined, when the Myrmigan poet is allocated the authority of the new state, it is understood that the Myrmigan poet, as magistrate, will act according to the welfare of the citizens. ${ }^{5}$

\section{Conclusion}

The themes that are encountered in Greek children's and young adults' science fiction describe the colonization of other planets by earthlings or of the Earth by extraterrestrials and in all cases the colonial approach-with plundering and destruction, economic exploitation and oppression-is avoided and is therefore condemned for both aesthetic and pedagogical reasons. The different objectives are due to the difference in age between adults and children, which essentially reflects the ideological gap between them. Adults, both earthlings and

\footnotetext{
${ }^{5}$ Aristotle, Politics (1954), "Since we see each city to be a society and each society to exist in order to do something good, it is apparent that all the cities and the societies are interested in doing the best. And exactly these cities and societies are called politics." Also, Politics, C, 1, 2: "because the citizen is impugned very often. Because they do not all accept that he is a citizen, for the reason that he who is a citizen in the democracy in oligarchy is usually not treated as a citizen."
} 
extraterrestrials - as representatives of colonial and imperialist intentions whose purpose is primarily to exploit the natural resources of other planets-are depicted with all the traits of classical colonists after the fifteen century (subservience of the colonised people, financial exploitation, plundering etc.). On the other hand, children, as expressers of moral values, aim for peaceful settlement on the planet and for harmonious collaboration with the inhabitants.

So, colonialism as it is described in literary narratives for children and young people seems to reflect "historical colonialism" -or better to reproduce it, emphasizing endless hard work. It is characteristic that colonial powers in these works do not rationalize their policies because their only objective is the economic exploitation of the regions that they colonize and, in fact, they never rationalize their policy, i.e. that subjected people either need their guidance or help to survive and to develop. What they are interested in is keeping the people on Earth or the planets subordinate and exploiting them. Any attempt by the subjected people to express their dissatisfaction towards the colonizers is either met with violence, stifled or cancelled.

Therefore, in "literary colonialism" after the fall of an empire, we encounter common characteristics in the way in which the people, who are now free, dynamically deal with the new situation. They are organized politically and socially with the help of enlightened people, who are now free since the collapse of the colonial system and try to reestablish their new polity based on the ideas about the polity as expressed by ancient Greek philosophers. This way of political settlement through democratic dialogue in literary colonial texts could be a universal pattern of the postcolonial settlement of a polity in colonial literature. Therefore, the way in which the intergalactic conquered people accept the fall of the empire of Myrmigana shows that they have recovered and reinforced the national identity that the colonizers did not allow to exist. This prohibition reflects not only the exploitation of the colonized people in its historical dimension but also the hard illiberal situations that depict a dystopian society and State in its literary allegory. Also, the fall of the empire, and every empire, gives a chance for the colonized people's political and cultural identity to be revealed as they express their repressed democratic ideals and subtle cultural sensitivities.

We also detect the same sensitivities in the novel, The Message (2001), by Papatheothorou. These sensitivities are expressed after the fall of the general monarch who has subjugated the citizens using a perfect technological mechanism. The overthrow of the monarch establishes and reinforces the national identity of the repressed people who now realize that they are capable of undertaking responsibilities themselves and defining their own political cultural identity, according to the democratic principles that have now been established.

Stories like these, essentially, depict major Western problems and generally, problems of the entire Earth in which overpopulation and the non active population of a country causes financial and social problems. The colonization of the two Asteroids reflects the attempt of contemporary man who is technologically developed to solve these problems by turning to the easy solution of expulsion 
from a familiar environment for individuals who "are expelled" from their family or society. The entire process constitutes a "refined" form of the policy once implemented by the ancient Spartans, who used to kill children with physical deformities by throwing them into the Caias gorge (Ceadas, in Greek). It also reflects the policy of these countries which, with the pretext of theoretically better care, secures people such as these in appropriate institutions. In many countries, however, in which domestic or social attachment is not as powerful, a policy like this is considered quite natural. The "colonial" concept goes beyond the known historical ("historical colonialism") or literary events of the colonials ("literary colonialism") and it is possible to foretell the attitudes of man in the future.

These texts prelude a postcolonial Eden in which children play an important role (Earth 2040 AD, The Last Country on Earth), even if they are subordinate to adults. In spite of the children's subordinate position in relation to adults, they eventually prove to be higher-minded and the ideas of liberation and decolonization that are expressed through children and their literature clash with the colonial disposition of adults and create utopian situations. Thus, what McGillis (1999: 225) argues "adults are the colonizers and children are the colonized" does not hold. Of course an instance in which children are shaped and organised by a multitudinous and dominant group may be inevitable if we accept that adults are responsible not only for retaining but also perpetuating a social order. Postcolonial literature, as a literary enterprise in which children are involved, can certainly touch them when their authors permit them to speak and when adults listen to them or are obliged to obey them. The novel Earth $2040 A D$ by Androutsopoulos succeeds in doing this brilliantly. The book clearly shows children as potentially ensuring a better way of life as they renounce the corrupt society, even when the adults promote their nostalgic desire for lost opportunities. Androutsopoulos's novel is significant because it is among the very few examples of Greek anticolonial children's science fiction that portrays the devastating effects of colonialism in this rupture between past and present, parent and child.

The selection of a space background, the effort to regain a lost civilisation and the history of colonised/postcolonial planets, such as those depicted in what are essentially the anticolonial science fiction stories that we are investigating, the merging of the intergalactic universe through the victory of the cicadas over the colonising ants and their reconciliation in an ecumenical neighbourhood, in which the oppression of the colonists is transformed into an intergalactic democratic postcolonial democracy without frontiers (Invasion of Myrmigana), the thwarting of the colonial disposition of the extraterrestrials (Zero Hour), the averting of the anthropoids' colonial plans (The Last Country on Earth) and the dissolution of the colonies on the asteroids (The Message) reveal an anticolonial ideology on the part of children's authors and their desire to create an ideal world. For this reason they give children an active role in their stories. But also when the children play a passive role or they are simply readers, children and young adults have the chance to see how colonial situations are encountered in the literary colonialism and acquire a democratic conscience. It is typical that these intentions are passed down to the readers in simple but delightful stories, rejecting 
stereotypes and the threatened colonialism of the contemporary world in any form whatsoever, especially economic and political, by those who implement imperialist and colonial policy. It is also typical that postcolonial situations are only rarely described but are signified more by the dissolution of colonies. Only the novel by Takis Androutsopoulos portrays the struggle to throw off colonialism and to make the transition to postcolonial states, in which life in all its manifestations (administration, society, economy and ethics) is organised by children who have now come of age with the guidance of their enlightened teacher. This however is a utopia, as children will never take control into their own hands in real life. Adults-colonists resist strongly and children are in danger of remaining always their "colonised territory".

Some texts are reminiscent of ancient Greek policy, with the hegemonic behaviour of the city-states and the Roman Empire. It is difficult to overlook the partly colonial nature of the expeditions of Alexander the Great, in spite of the civilising mantle in which they have been wrapped. Nobody can doubt the abusive interventions by certain states in our time, which have left a "civilising" version of modern colonialism and authoritarianism, mainly at the level of political infiltration and economic dependency. The powerful of the Earth exploit the economically weak peoples (financial colonialism), who are tormented by the economic dependency and political infiltration that are used to control the political scene in small countries all over the planet, mainly through military intervention, as in Myrmigana. Only an objective view of these historical events can give the true dimension to science fiction texts in which a political allegory is artfully concealed.
These texts initiate the readers into anticolonialism and democracy, revealing the illusions with which an authoritarian and colonial government lulls its citizens into inertia, terrorising the colonised inhabitants of planetary or intergalactic systems and manipulating them through exploitation and the deprivation of their freedom.

These texts develop anticolonial awareness in their young readers based on historical reality and the possibly unconfessed aims of the powerful who attempt, through science fiction for children and young people, to pass on political systems and colonial practices into the cosmic world, space and outer space, even if political visions are expressed as utopia. The transfer of the population to another planet under aggravating circumstances prepares contemporary man for similar transfers in the future since, in real life, travels for research have already begun and these travels have the target both to exploit the planets and to save mankind.

In the final analysis, colonial and postcolonial Greek science fiction seems to portray a world on the threshold of an incoming "civilisation," a world that has not yet been domesticated by substantial humane education and is still encoded by the ideology of economic exploitation and oppression. In essence, however, through its colonial and postcolonial narrations, it creates myths to promote the value of man in his ethical, humanitarian, social and financial dimensions, even if an unlimited exploitation of the colonised space (Invasion of Myrmigana) is depicted. 


\section{References}

Androutsopoulos, Takis. 1999. Earth 2040 $A D$ (Gi 2040 m.X.). Athens: Potamos.

Aristotle. 1954. Politics. Athens: Zaharopoulos.

Childs, Peter and William Patrick. 1997. An Introduction to Post-Colonial Theory. New York: Prentice-Hall.

Dalziell, Tanya. 2004. Colonial Displacements: Another Look at Miles Franklin's My Brilliant Career. Ariel 35.4: 39-56.

Disch, Thomas. 1998. The Dreams Our Stuff Is Made Off. New York: The Free Press.

Jacoby, Russell. 1995. Marginal Returns: The Trouble with Post-colonial Theory. Lingua Franca: 30-37.

Kakoulli, Toula. 1990. The Last Country on Earth (I teleytaia Xora tis Gis). Nicosia.

---. 1990. Zero Hour (Ora Miden ). Nicosia.

Laskaratos, Andreas. 1888. Voyage to the Planet Jupiter (Taxidi ston Planiti Dia ). Athens, V. I.

Loomba, Ania. 1998. Colonialism/ Post colonialism, The New Critical Idiom. London and New York. Routledge.

Lowry, Lois. 2008. The Giver. London: HarperCollins.

McGillis, Roderick (ed.). 1999. Introduction. Voices of the Other, Children's Literature and the Postcolonial Context. McGillis Roderick (ed.). New York \& London: Garland,: xix-xxxii.

---. 1999. "And the Celt Knew the Indian": Knowingness, Post colonialism, Children's Literature. Voices of the Other, Children's Literature and the Postcolonial Context, pp. 223-235. New York and London: Garland.

McLeod, John. 2000. Beginning Postcolonialism. Manchester: Manchester UP.

Papantonakis, George. 2005. Greek Children's Science Fiction: From Colonialism to Children's Democratic Education. Educational Currents in the Aegean. International Journal for Pedagogical Discussion, $<$ www.pre.aegean.gr/revmata 2>

Papatheodorou, Vassilis. 2001. The Message (To Mynima ). Athens: Kastaniotis.

Paschos, Vasilis. 1979a. The Astronaut The Conciliator. Athens: (Publisher unknown).

---. 1979b. The Extraterrestrials Surprise Us. Athens: (Publisher unknown).

---. 1989. A Travel To The Stars. Athens: Mokas-Morfotiki.

Plato. 1958. Republic. Athens: Zaharopoulos.

Stephens, John. 1992. Language and Ideology in Children's Fiction. London and New York, Longman. 
Verettas, Marios. 1997. Invasion of Myrmigana (Eisvoli sti Myrmigana). Athens: Marios Verettas.

Voutyras, Demosthenes. 1929. From Earth to Mars (Apo ti Gi ston Ari). Athens: Dimitrakos.

---. 1930. To Unknown Gods (Stous Agnostous Theous). Athens:

Dimitrakos

---. 1934. Kalpikoi Politismoi (False Civilisations). Athens: the newspaper Anexartitos (Independence).

Vrettakos, Nikiforos. 1990. The Poems. Athens: Three Leaves.

Wells, H. G. 2006. The War of the Worlds. Clayton: Prestwick House,Inc. 